\title{
Insulin resistance induced by growth hormone is linked to lipolysis and associated with suppressed pyruvate dehydrogenase activity in skeletal muscle: a $2 \times 2$ factorial, randomised, crossover study in human individuals
}

\author{
Astrid J. Hjelholt ${ }^{1,2}$ (D) Evelina Charidemou ${ }^{3}$ (D) Julian L. Griffin $^{3}$ (D) Steen B. Pedersen $^{1}$ (D) Anders Gudiksen $^{4}$ (D) \\ Henriette Pilegaard ${ }^{4}$ (D) Niels Jessen ${ }^{2,5,6}$ (D) Niels Møller ${ }^{1}$ (D) - Jens O. L. Jørgensen ${ }^{1}$ (D)
}

Received: 8 June 2020 / Accepted: 15 July 2020 / Published online: 18 September 2020

(C) Springer-Verlag GmbH Germany, part of Springer Nature 2020

\begin{abstract}
Aims/hypothesis Growth hormone $(\mathrm{GH})$ causes insulin resistance that is linked to lipolysis, but the underlying mechanisms are unclear. We investigated if GH-induced insulin resistance in skeletal muscle involves accumulation of diacylglycerol (DAG) and ceramide as well as impaired insulin signalling, or substrate competition between fatty acids and glucose.

Methods Nine GH-deficient male participants were randomised and examined in a $2 \times 2$ factorial design with and without administration of GH and acipimox (an anti-lipolytic compound). As-treated analyses were performed, wherefore data from three visits from two patients were excluded due to incorrect $\mathrm{GH}$ administration. The primary outcome was insulin sensitivity, expressed as the AUC of the glucose infusion rate $\left(\mathrm{GIR}_{\mathrm{AUC}}\right)$, and furthermore, the levels of DAGs and ceramides, insulin signalling and the activity of the active form of pyruvate dehydrogenase (PDHa) were assessed in skeletal muscle biopsies obtained in the basal state and during a hyperinsulinaemic-euglycaemic clamp (HEC).

Results Co-administration of acipimox completely suppressed the GH-induced elevation in serum levels of NEFA (GH versus GH+acipimox, $p<0.0001$ ) and abrogated GH-induced insulin resistance (mean $\mathrm{GIR}_{\mathrm{AUC}}[95 \% \mathrm{CI}]\left[\mathrm{mg} \mathrm{min}^{-1} \mathrm{~kg}^{-1}\right] \mathrm{during} \mathrm{the}^{-}$ HEC: control, 595 [493, 718]; GH, 468 [382, 573]; GH+acipimox, 654 [539, 794]; acipimox, 754 [618, 921]; GH vs GH+ acipimox: $p=0.004)$. GH did not significantly change either the accumulation of DAGs and ceramides or insulin signalling in skeletal muscle, but GH antagonised the insulin-stimulated increase in PDHa activity (mean \pm SEM [\% from the basal state to the HEC]: control, $47 \pm 19$; GH, $-15 \pm 21$; GH+acipimox, $3 \pm 21$; acipimox, $57 \pm 22$; main effect: $p=0.02$ ).

Conclusions/interpretation GH-induced insulin resistance in skeletal muscle is: (1) causally linked to lipolysis; (2) not associated with either accumulation of DAGs and ceramides or impaired insulin signalling; (3) likely to involve substrate competition between glucose and lipid intermediates.

Trial registration ClinicalTrials.gov NCT02782208

Funding The work was supported by the Grant for Growth Innovation (GGI), which was funded by Merck KGaA, Darmstadt, Germany.
\end{abstract}

Keywords Acipimox · Ceramides · Diacylglycerols · Fatty acids · Growth hormone · Insulin resistance · Insulin signalling · Pyruvate dehydrogenase activity

Electronic supplementary material The online version of this article (https://doi.org/10.1007/s00125-020-05262-w) contains peer-reviewed but unedited supplementary material, which is available to authorised users.

Astrid J. Hjelholt

ajh@clin.au.dk

Extended author information available on the last page of the article

$\begin{array}{ll}\text { Abbreviations } \\ \text { ACN } & \text { Acetonitrile } \\ \text { AS160 } & \text { Akt substrate of } 160 \mathrm{kDa} \\ \text { DAG } & \text { Diacylglycerol } \\ \text { EGP } & \text { Endogenous glucose production } \\ \text { GH } & \text { Growth hormone } \\ \text { GHD } & \text { GH deficiency } \\ \text { GIR } & \text { Glucose infusion rate }\end{array}$

\section{Abbreviations}

ACN Acetonitrile

EGP Endogenous glucose production

Growth hormone

GIR Glucose infusion rate 


\section{Research in context}

\section{What is already known about this subject?}

- Growth hormone (GH)-induced insulin resistance is linked to the concomitant increase in circulating NEFA

What is the key question?

- Is GH-induced insulin resistance associated with (1) accumulation of diacylglycerols and ceramides in skeletal muscle and impaired insulin signalling or (2) substrate competition between fatty acids and glucose?

\section{What are the new findings?}

- GH-induced insulin resistance is not associated with either accumulation of diacylglycerols and ceramides or impaired insulin signalling

- The GH-induced suppression of insulin-stimulated active pyruvate dehydrogenase activity suggests that substrate competition between fatty acids and glucose is involved in $\mathrm{GH}$-induced insulin resistance in skeletal muscle

How might this impact on clinical practice in the foreseeable future?

- These data provide fundamental insight into fatty acid-driven insulin resistance, which is of importance for understanding the metabolic syndrome, insulin resistance and type 2 diabetes

GIR $_{\text {AUC }} \quad$ AUC of the GIR

GS Glycogen synthase

GSK Glycogen synthase kinase

HEC Hyperinsulinaemic-euglycaemic clamp

IPA Isopropanol

NOGD Non-oxidative glucose disposal

$\mathrm{PDH} \quad$ Pyruvate dehydrogenase

PDHa The active form of PDH

PDK Pyruvate dehydrogenase kinase

$R_{\mathrm{a}} \quad$ Glucose rate of appearance

$R_{\mathrm{d}} \quad$ Glucose rate of disappearance

UHPLC Ultra-high-performance liquid chromatography system

\section{Introduction}

Growth hormone (GH) directly stimulates lipolysis [1], which is detectable as an increase in circulating levels of NEFA 1$2 \mathrm{~h}$ after a $\mathrm{GH}$ bolus [2, 3]. Concomitantly, GH induces insulin resistance in skeletal muscle as evidenced by a decrease in muscle glucose uptake [2, 4].

It is well known that fatty acids induce insulin resistance in skeletal muscle [5-9] and the mechanisms have been suggested to involve impaired insulin signalling induced by intramyocellular lipid accumulation [10-14] and/or substrate competition between fatty acids and glucose [8].

Substrate competition, or the glucose-fatty acid cycle, as proposed by Randle et al, implies that enhanced fatty acid oxidation increases mitochondrial acetyl-CoA and NADH, which inhibits pyruvate dehydrogenase $(\mathrm{PDH})$ activity, and thereby the conversion of pyruvate into acetyl-CoA. This ultimately leads to accumulation of glucose 6-phosphate and reduced glucose uptake [8]. Other studies, however, reported that intravenous infusion of lipid induced insulin resistance by reducing insulin signalling and action in human skeletal muscle [11-13]. This led to the hypothesis that fatty acids inhibit insulin-stimulated glucose uptake secondary to intramyocellular accumulation of certain lipid intermediates that directly impair insulin signalling [10, 14].

Several experimental studies have shown that pharmacological inhibition of lipolysis resulting in low serum NEFA levels abolishes GH-induced insulin resistance in human individuals [15-18]. Furthermore, we have observed GH-induced suppression of active PDH (PDHa) activity in healthy human volunteers concomitantly with normal insulin signalling [19].

Taken together, this suggests that $\mathrm{GH}$-induced insulin resistance is causally linked to lipolysis, but the underlying mechanisms remain to be experimentally tested. We therefore designed a study to elucidate the metabolic effects of $\mathrm{GH}$ in the presence and absence of activated lipolysis. To this end, nine hypopituitary adults with GH deficiency (GHD) were studied in a $2 \times 2$ factorial design including GH replacement therapy and treatment with acipimox, a nicotinic acid derivative that blocks protein kinase A-dependent lipolysis via suppression of adenylyl cyclase [20]. The outcomes included insulin sensitivity, basal and insulin-stimulated insulin signalling, intramuscular content of diacylglycerols (DAGs) and ceramides, and PDHa activity in skeletal muscle.

\section{Methods}

\section{Participants and study design}

In a $2 \times 2$ factorial, randomised, crossover design, nine hypopituitary men with documented GHD receiving stable $\mathrm{GH}$ 
replacement therapy were studied. Both participants and investigators were blinded to the intervention, excluding $\mathrm{GH}$ administration. Eligibility criteria included age over 18, male sex and documented GHD. None of the patients had diabetes or any overt chronic disease. The participants were in the age range of 29-71 years and had a mean \pm SEM BMI of $28.2 \pm$ $0.9 \mathrm{~kg} / \mathrm{m}^{2}$. The study was carried out in the Medical Research Laboratory, Aarhus University, and was conducted in accordance with the Declaration of Helsinki II, approved by the regional Ethics Committee System and reported at ClinicalTrials.gov (registration no. NCT02782208). Oral and written consents were obtained from all participants prior to inclusion. Data on serum NEFA levels, lipoprotein lipase activity and expression of ANGPTL4 mRNA (which encodes angiopoietin-like 4) from this study have been published previously [21].

\section{Protocol}

Each participant was studied on four separate occasions after: (1) discontinuation of GH injections for $36 \mathrm{~h}$ plus oral placebo ('control'); (2) continuation of GH injections plus oral placebo ('GH'); (3) continuation of GH injections plus oral acipimox ('GH+acipimox'); and (4) discontinuation of GH injections for $36 \mathrm{~h}$ plus oral acipimox ('acipimox'), respectively. Oral acipimox (Olbetam, Orifarm Generics, Denmark) in a dose of $250 \mathrm{mg}$ or placebo was administrated at 20:00 and 23:00 hours on the evening before and at 06:00 and 10:00 hours on each of the four study days (Fig. 1). The pharmacy at Aarhus University Hospital undertook randomisation, blinding and provision of acipimox/placebo. Block randomisation was used and the random allocation sequence was stored in sealed envelopes until the study was unblinded after all participants had completed the study. GH was administered as subcutaneous self-injections at 22:00 hours. During the acipimox and control experiments, GH injections were discontinued 2 days prior to the study day. Replacement therapy with other hormones was continued.

The metabolic studies were performed between 8:00 and 14:00 hours $(t=0-360)$ after an overnight fast. The participants were instructed to refrain from alcohol intake and vigorous exercise for 2 days prior to the study day. On each study day, an intravenous catheter for infusions was inserted in the antecubital vein of one arm, and another catheter was placed in a contralateral hand vein, which was heated to obtain arterialised blood. Blood samples were drawn at $t=0,60$, $120,160,170,180,240,300,340,350$ and $360 \mathrm{~min}$. A $3 \mathrm{~h}$ basal period (0-180 $\mathrm{min}$ ) was followed by a $3 \mathrm{~h}(180-360 \mathrm{~min})$ hyperinsulinaemic-euglycaemic clamp (HEC) with continuous insulin infusion $\left(0.6 \mathrm{mU} \mathrm{min} \mathrm{mg}^{-1} \mathrm{~kg}^{-1}\right.$, Humulin Regular, Eli Lilly, Denmark). During the HEC, plasma glucose concentrations were measured at bedside every $10 \mathrm{~min}$ and the glucose infusion rate (GIR) was adjusted with a $20 \%$ glucose infusion to maintain euglycaemia ( $5 \mathrm{mmol} / \mathrm{l})$. The $M$ value was calculated as mean GIR ( $t=340-360 \mathrm{~min})$ per $\mathrm{kg}$ body mass.

\section{Tracer kinetics}

A bolus $(0.74 \mathrm{MBq})$ of $\left[3-{ }^{3} \mathrm{H}\right]$-glucose (GE Healthcare, Denmark) was given at $t=0$ followed by a continuous

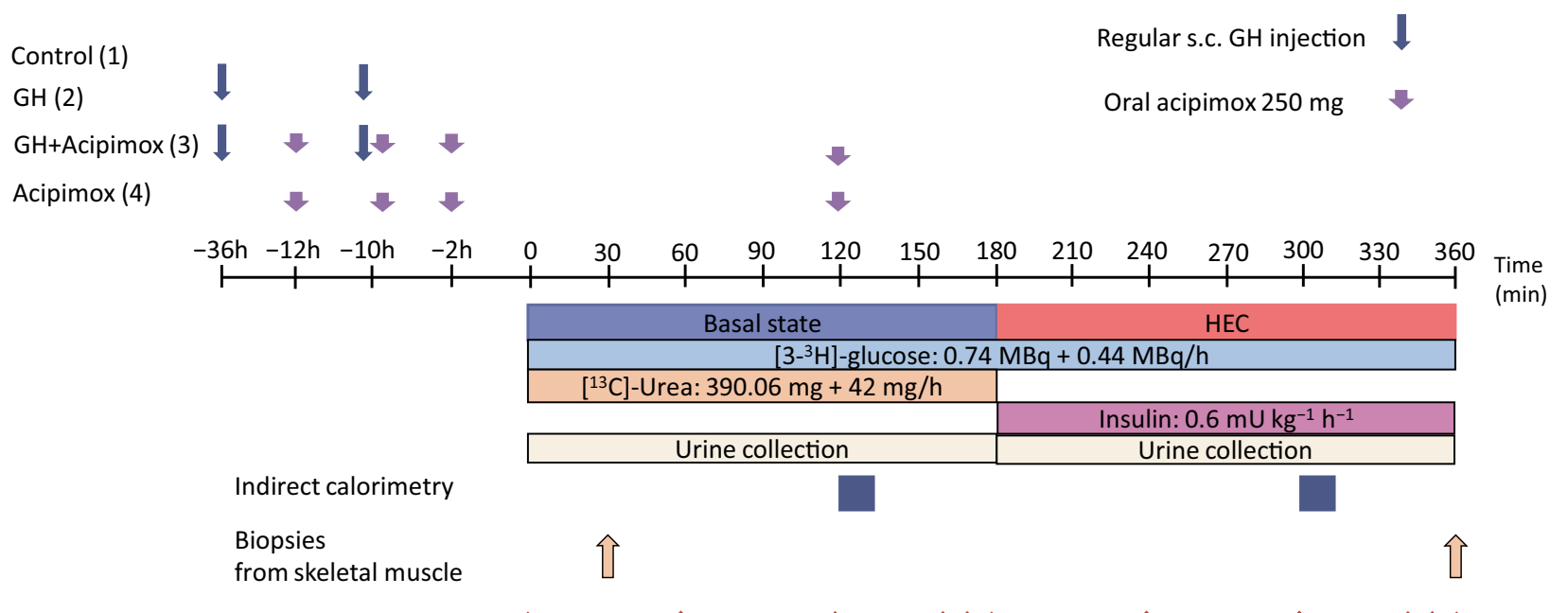

Blood sampling

Fig. 1 Study design. The participants were studied after: (1) discontinuation of GH injections plus oral placebo tablets (control); (2) continuation of GH plus oral placebo tablets (GH); (3) continuation of GH plus oral acipimox tablets (GH+acipimox); and (4) discontinuation of GH plus oral acipimox tablets (acipimox). Oral acipimox was administered at 20:00 and 23:00 hours the evening before and at 06:00 and 10:00 hours on the study day and GH was administered as subcutaneous self-injections at

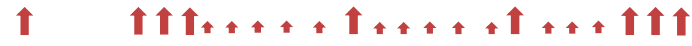

22:00 hours. The study day commenced with a $3 \mathrm{~h}$ basal period $(0$ $180 \mathrm{~min})$ followed by a $3 \mathrm{~h} \mathrm{HEC} \mathrm{(180-360} \mathrm{min).} \mathrm{Biopsies} \mathrm{were} \mathrm{obtained}$ in the basal state and during the HEC. Blood samples were drawn at $t=0$, $60,120,160,170,180,240,300,340,350$ and $360 \mathrm{~min}$ (large red arrows), and furthermore, plasma glucose concentrations were measured at the bedside every 10 min to adjust the GIR during the HEC (small red arrows) 
infusion $(0.44 \mathrm{MBq} / \mathrm{h})$ at $t=0-360 \mathrm{~min}$. In addition, $\left[3-{ }^{3} \mathrm{H}\right]-$ glucose was added to the glucose infused during the HEC to avoid rapid dilution $\left(3.7 \mathrm{MBq}\left[3{ }^{3} \mathrm{H}\right]\right.$-glucose in $500 \mathrm{ml}$ of $20 \%$ glucose). Specific activities of $\left[3-{ }^{3} \mathrm{H}\right]$-glucose were measured in triplicates at the end of the basal period $(t=$ $160-180 \mathrm{~min})$ and the HEC ( $t=340-360 \mathrm{~min})$. Glucose rate of appearance $\left(R_{\mathrm{a}}\right)$ and glucose rate of disappearance $\left(R_{\mathrm{d}}\right)$ were calculated using the non-steady-state equation of Steele [22]. Endogenous glucose production (EGP) equals $R_{\mathrm{a}}$ in the basal period, whereas EGP during the HEC was calculated by subtracting GIR from $R_{\mathrm{a}}$. Non-oxidative glucose disposal (NOGD) was calculated by subtracting oxidative glucose disposal (derived from indirect calorimetry, see below) from total $R_{\mathrm{d}}$

To obtain a measure of protein degradation, $\left[{ }^{13} \mathrm{C}\right]$-urea was administered in the basal state $(t=0-180 \mathrm{~min})$ as a $390.6 \mathrm{mg}$ bolus followed by a continuous infusion of $42 \mathrm{mg} / \mathrm{h}$ and was measured in triplicates at the end of the basal period $(t=160$ $180 \mathrm{~min})$.

\section{Indirect calorimetry}

Indirect calorimetry was performed with a canopy system (Oxycon Pro; Intramedic, Gentofte, Denmark) in the basal state $(t=120)$ and during the HEC $(t=300)$ to estimate energy expenditure, respiratory exchange ratio and substrate oxidation rate as previously described [23]. Urine was collected in the basal period and during the HEC to estimate protein oxidation based on urea excretion.

\section{Biopsies}

Skeletal muscle biopsies were obtained in the basal state ( $t=$ $30)$ and during the HEC $(t=360)$. The biopsies were obtained from the vastus lateralis of the quadriceps femoris muscle under sterile conditions using a Bergström needle. Lidocaine was used as local anaesthetic and the biopsies were immediately washed free of blood, frozen in liquid nitrogen and stored at $-80^{\circ} \mathrm{C}$ until analysis.

\section{Blood samples}

Plasma glucose and lactate levels were measured at bedside (YSI 2300 STAT Plus glucose analyser; YSI, Burlington, VT, USA). Commercial ELISA kits were used to analyse insulin (Merkodia, Uppsala, Sweden), glucagon (Merkodia, Uppsala, Sweden) and cortisol (DRG Diagnostics, Marburg, Germany). Serum NEFA levels were determined by a colorimetric method using a commercial kit (Wako Chemicals, Neuss, Germany). Serum GH concentrations were determined by a modified chemiluminescence technology (IDS-iSYS human GH; Immunodiagnostic Systems, Boldon, UK). Plasma adrenaline (epinephrine) and noradrenaline (norepinephrine) concentrations were measured by electrochemical detection following HPLC separation.

\section{Quantitative PCR}

Quantitative PCR analyses were performed as previously described [24]. B2M (encoding $\beta 2$ microglobulin) was used as housekeeping gene, as mRNA levels were similar between interventions. Primer sequences of $B 2 M$ were GAGGCTAT CCAGCGTACTCC and AATGTCGGATGGATGAAACC $\mathrm{C}$ (length 111), primer sequences of $P D K 2$ were AGCCGATTCACATGGTCTACGTC and AGTCGCCC TCATGGCATTCTTG (length 80 ), and primer sequences of $P D K 4$ were ATTTAAGAATGCAATGCGGGC and GCGGTCAATAATTCTCAGGG (length 151). The fold change was calculated using the $2^{-\Delta \Delta \mathrm{C}_{\mathrm{t}}}$ method, where $\Delta \Delta C_{t}$ is the difference between the mean $C_{t}$ for the target gene and the housekeeping gene at time $x$, minus the difference between the mean $\mathrm{C}_{\mathrm{t}}$ for the target gene and the housekeeping gene in the basal state on the control day. The efficiency of the PCR reaction was similar for $B 2 M$ and each of the target genes, verifying that the $\Delta \Delta \mathrm{C}_{\mathrm{t}}$ method can be used.

\section{Capillary electrophoresis immunoassay (Wes system)}

Phosphorylation of signalling proteins was measured by capillary electrophoresis immunoassay (Wes; ProteinSimple, Santa Clara, CA, USA) as previously described $[25,26]$. Detailed information regarding the antibodies is provided in the electronic supplementary material (ESM) Table 1. All antibodies were diluted 1:25 in Antibody Dilution (ProteinSimple), and the tissue samples were homogenised in a buffer containing $50 \mathrm{mmol} / 1 \mathrm{HEPES}, 137 \mathrm{mmol} / 1 \mathrm{NaCl}, 10 \mathrm{mmol} / 1 \mathrm{Na}_{4} \mathrm{P}_{2} \mathrm{O}_{7}$, $20 \mathrm{mmol} / 1 \mathrm{NaF}, 5 \mathrm{mmol} / 1 \mathrm{EDTA}, 1 \mathrm{mmol} / 1 \mathrm{MgCl}_{2}, 1 \mathrm{mmol} / \mathrm{l}$ $\mathrm{CaCl}_{2}, \mathrm{NP}-40,2 \mathrm{mmol} / \mathrm{l} \mathrm{NaOV}, 5 \mathrm{mmol} / \mathrm{l} \mathrm{NAM}, 10 \mu \mathrm{mol} / \mathrm{l}$ TSA, HALT, glycerol and demineralised water. After $1 \mathrm{~h}$ of agitation at $4{ }^{\circ} \mathrm{C}$, the samples were spun at $16,200 \mathrm{~g}$ for $20 \mathrm{~min}$ and the supernatant was used. Protein concentration was measured with a bicinchoninic acid (BCA) assay. Samples were vortex mixed with mastermix (ProteinSimple) and heated at $95^{\circ} \mathrm{C}$ for $5 \mathrm{~min}$. Protein content and phosphorylation were quantified as peak area for the protein of interest, and phosphorylation levels were expressed as the ratio between phosphorylation and total content of the protein.

\section{PDHa activity}

PDHa activity was measured as previously described [19]. In short, $8-15 \mathrm{mg}$ of the muscle tissue was homogenised on ice for $50 \mathrm{~s}$ using a micro glass homogeniser (Kontes, Vineland, NJ, USA) and snap-frozen in liquid nitrogen. The PDHa activity in the homogenate was determined from the rate of acetyl- 
CoA production using a radioactivity assay $[27,28]$ and normalised to the content of creatine in the sample.

\section{Measurement of metabolite levels by mass spectrometry}

Metabolite extractions Metabolites were extracted from skeletal muscle tissues using a modified method of Folch et al [29]. Briefly, $30 \mathrm{mg}$ wet weight of tissue was homogenised in chloroform/methanol (2:1, vol./vol., $750 \mu \mathrm{l})$ using a TissueLyser (Qiagen, Manchester, UK). Samples were sonicated for $15 \mathrm{~min}$ and demineralised water and chloroform were added ( $200 \mu \mathrm{l}$ of each). Separation of the aqueous and organic fractions was performed following centrifugation $(13,000 \mathrm{~g}$ for $20 \mathrm{~min})$. The organic phase (lower phase) extracts containing lipids were dried under a stream of nitrogen gas. A mixture of ${ }^{2} \mathrm{H}$-labelled internal standards was added to the fractions and dried again under nitrogen (ESM Table 2).

\section{Analysis of intact lipids using orbitrap mass spectrometry The} organic fraction was reconstituted in $100 \mu \mathrm{l}$ of chloroform/ methanol (1:1, vol./vol.), and $10 \mu \mathrm{l}$ of the resulting solution was added to $190 \mu \mathrm{l}$ of isopropanol (IPA)/acetonitrile (ACN)/ water (2:1:1, vol./vol.). Samples were analysed using an LTQ Orbitrap Elite Mass Spectrometer (Thermo Scientific, Hemel Hempstead, UK). Sample ( $5 \mu \mathrm{l})$ was injected onto a C18 CSH column (Waters, Manchester, UK; $1.7 \mu \mathrm{mol} / 1$ pore size, $2.1 \mathrm{~mm} \times 50 \mathrm{~mm}$ ), which was held at $55^{\circ} \mathrm{C}$ in a Dionex Ultimate 3000 ultra-high-performance liquid chromatography system (UHPLC; Thermo Scientific). A gradient (flow rate $0.5 \mathrm{ml} / \mathrm{min}$ ) of mobile phase A (ACN/water, 60:40) and B (LC-MS-grade ACN/IPA, 10:90), with either $10 \mathrm{mmol} / 1$ ammonium formate (positive mode) or $10 \mathrm{mmol} / \mathrm{l}$ ammonium acetate (negative mode), was used. In both positive and negative ion modes, the gradient run began at $40 \% \mathrm{~B}$; increased to $43 \% \mathrm{~B}$ at $0.8 \mathrm{~min}, 50 \% \mathrm{~B}$ at $0.9 \mathrm{~min}, 54 \% \mathrm{~B}$ at $4.8 \mathrm{~min}, 70 \% \mathrm{~B}$ at $4.9 \mathrm{~min}, 81 \% \mathrm{~B}$ at $5.8 \mathrm{~min}$; peaked at $99 \% \mathrm{~B}$ at $8 \mathrm{~min}$ for $0.5 \mathrm{~min}$; and subsequently returned to the starting conditions for another $1.5 \mathrm{~min}$ to re-equilibrate the column. The UHPLC was coupled to an electrospray ionisation (ESI) source, which ionised the analytes before entering the mass spectrometer. Spectra were collected in both positive and negative ion modes in the range of $110-2000 \mathrm{~m} / \mathrm{z}$. Default instrumentgenerated optimisation variables were used (ESM Table 3).

The spectra files were converted to mzML format and features picked using XCMS (https://xcmsonline.scripps. edu/ version 3.5) [30], after retention time alignment. Lipid identification was performed using an in-house $\mathrm{R}$ script. Peak areas of each metabolite were normalised to the appropriate internal standard and tissue weight.

\section{Statistics}

Data were analysed to investigate $\mathrm{GH}$ and acipimox effects in the basal state and during the HEC; the relative change from basal to HEC as an additional measure of insulin responsiveness was also tested. Circulating hormones and metabolites were analysed as AUC during the basal state and the HEC.

The effects of GH and acipimox were assessed by repeated measurement mixed effects model analysis using the Restricted Maximum Likelihood method in STATA (https:// www.stata.com/ version 14.2, StataCorp). The model included GH (GH vs no GH treatment), acipimox (acipimox vs placebo), visit order and the interaction between GH and acipimox as fixed effects, and visit nested within-subject as random effect. To correct for multiple testing in the analyses of the content of ceramides and DAGs in skeletal muscle, the Holm-Bonferroni method was used.

To obtain homogeneous variance, unequal variance variables were logarithmically transformed. To account for missing values, Kenward Roger's approximation was used for calculation of degrees of freedom in all models. The results of the statistical analyses are given by the $p$ values. All analyses were performed as two-tailed tests. When an interaction or a main effect was present, pertinent pairwise comparisons were made. A $p$ value of $<0.05$ was considered statistically significant. As-treated analyses were performed, and therefore data from three visits from two different patients were excluded due to incorrect $\mathrm{GH}$ administration, resulting in $N=9$ on the control day, $N=7$ on the GH day, $N=9$ on the GH+acipimox day and $N=8$ on the acipimox day. Furthermore, three skeletal muscle biopsies were excluded because of fat contamination, two from the GH+acipimox day and one from the acipimox day, resulting in $N=9$ on the control day, $N=7$ on the GH day, $N=7$ on the GH+acipimox day and $N=7$ on the acipimox day in the protein and quantitative PCR analyses.

All graphical presentations were performed with SigmaPlot (http://www.sigmaplot.co.uk/, version 14.0, Systat Software). Data are presented as mean \pm SEM (blood analyses and substrate oxidation), or as geometric mean $\pm 95 \% \mathrm{CI}$.

The primary outcome was insulin sensitivity, expressed as the AUC of the GIR (GIR $\mathrm{GUC}_{\mathrm{AUC}}$ ) during the HEC and the $M$ value. Secondary outcomes were insulin signalling, content of DAGs and ceramides, and PDHa activity in the skeletal muscle. The sample sizes were defined based on a previous study [15].

\section{Results}

\section{Circulating hormones}

Serum GH levels increased during GH replacement therapy both in the basal state (main effect: $p<0.0001$ ) and during the HEC (main effect: $p<0.0001$ ), and acipimox evoked a 
minute, but detectable, increase in endogenous GH secretion in the basal state (main effect: $p=0.02$ ) (Fig. 2a). Serum glucagon levels were elevated by acipimox in the basal state (main effect: $p=0.0002$ ) and suppressed in response to insulin (main effect: $p<0.0001$ ) (Fig. 2b). Basal plasma lactate levels were similar in the four study arms and increased in response to insulin irrespective of GH and acipimox (main effect: $p<0.0001$ ) (Fig. 2c). Circulating cortisol levels decreased with time (main effect: $p<0.0001$ ) with no significant effect of either GH or acipimox (Fig. 2d). Basal and insulinstimulated adrenaline (Fig. 2e) and noradrenaline (Fig. 2f) levels were similar between the four interventions.

\section{Lipid metabolism}

Data on serum NEFA levels are previously described [21]. In short, basal serum NEFA levels were increased by GH (control vs GH: $p=0.03$ ), whereas NEFA levels were potently suppressed by acipimox (GH vs GH+acipimox: $p<0.0001$, control vs acipimox: $p<0.0001$ ) (Fig. 3a). In the presence of acipimox, GH exerted no residual effect on NEFA (GH+ acipimox vs acipimox: $p=0.43$ ). Insulin suppressed serum NEFA levels during all four interventions (main effect: $p<0.0001)$. Lipid oxidation in the basal state was decreased by acipimox (main effect: $p=0.0008$ ), whereas during the HEC, lipid oxidation decreased (main effect: $p<0.0001$ ) to comparable levels irrespective of treatment (Fig. 3b).

\section{Glucose metabolism and insulin sensitivity}

Basal plasma glucose levels were decreased by acipimox (main effect: $p=0.005$ ) (Fig. 4a), whereas comparable and stable glucose levels were obtained in all four interventions at the end of the HEC $(t=340-360)$. GH increased basal serum insulin levels relative to control $(p=0.02)$, and this increase was abrogated by acipimox ( $\mathrm{GH}$ vs $\mathrm{GH}+$ acipimox:
Fig. 2 Circulating hormones. Circulating levels of GH (a), glucagon (b), lactate (c), cortisol (d), adrenaline (e) and noradrenaline (f) in the basal state and during the HEC, presented as mean \pm SEM, $N=7-9$. Data were analysed by repeated measurement mixed effects model analysis. Main effect of GH: ${ }^{\dagger \dagger} p<0.01,{ }^{\dagger \dagger} p<0.001$; main effect of acipimox: ${ }^{\star} p<0.05,{ }^{* \dagger} p<0.001$
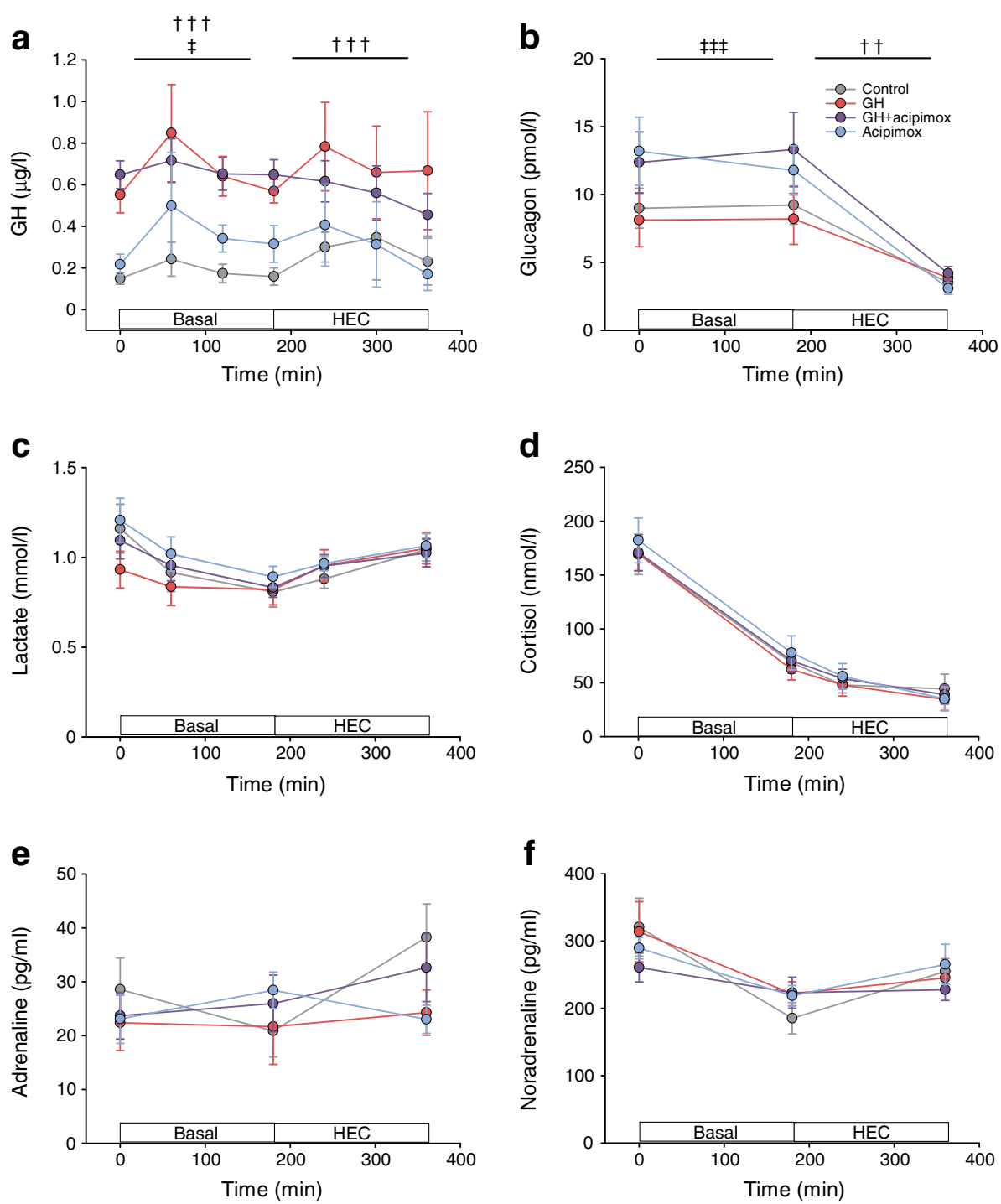
Fig. 3 NEFA metabolism and lipid oxidation. Serum NEFA levels (a) and lipid oxidation (b) in the basal state and during the HEC, presented as mean \pm SEM, $N=7-9$. Data were analysed by repeated measurement mixed effects model analysis. Interaction between GH and acipimox: $* p<0.05$; main effect of acipimox: ${ }^{\ddagger} p<0.05,{ }^{+1} p<0.001$
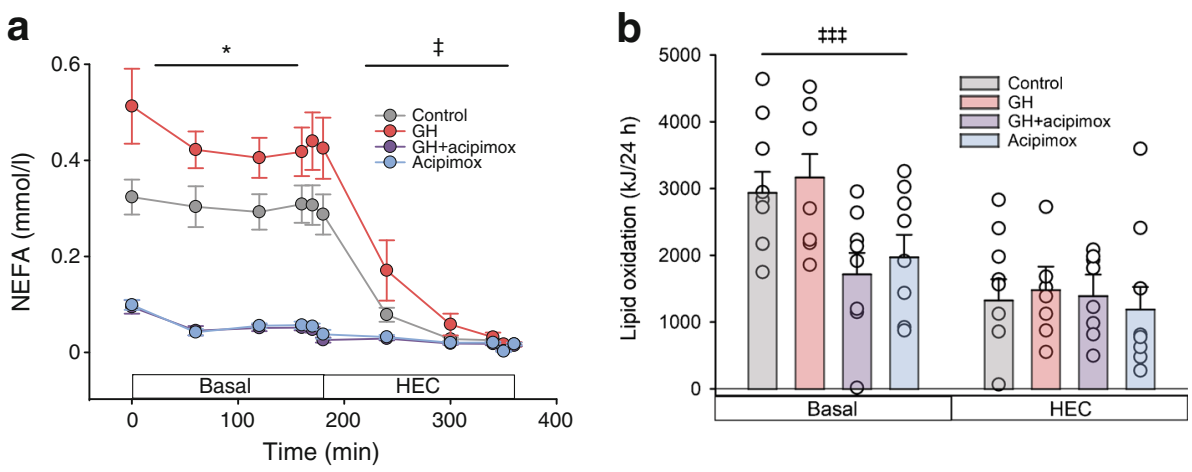

$p=0.002$ ). During the HEC, there was no significant difference in serum insulin levels between the four interventions (Fig. 4b).

Assessment of insulin sensitivity was based on $\mathrm{GIR}_{\mathrm{AUC}}$ and the $M$ value. GIR ${ }_{\text {AUC }}$ (control, 595 [493, 718]; GH, 468 [382, 573]; GH+acipimox, 654 [539, 794]; acipimox, 754 [618, 921]) was decreased by GH (control vs GH: $p=0.04$ ) and increased by acipimox (GH vs $\mathrm{GH}+$ acipimox: $p=0.004$; control vs acipimox: $p=0.03$ ), with no effect of $\mathrm{GH}$ during acipimox treatment $(\mathrm{GH}+$ acipimox vs acipimox: $p=0.2$ ) (Fig. $4 \mathrm{c}$ ). The $M$ value was reduced by $\mathrm{GH}$ as compared with control $(p=0.005)$, which was abolished by acipimox (GH vs $\mathrm{GH}+$ acipimox: $p=0.02$ ) (Fig. 4d). There was no significant difference in the $M$ value between control, GH+acipimox and acipimox alone.

Glucose disposal expressed by the $R_{\mathrm{d}}$ was similar on all study days in the basal state. During the HEC, GH decreased $R_{\mathrm{d}}$ (main effect: $p=0.01$ ), whereas acipimox evoked a nonsignificant increase (main effect: $p=0.06$ ) (Fig. 4e). Glucose oxidation in the basal state was increased by acipimox irrespective of GH (main effect: $p=0.004$ ); during the HEC, glucose oxidation increased to similar levels in all four interventions (Fig. 4f). NOGD in the basal state was suppressed by acipimox (main effect: $p=0.0009$ ). During the HEC, a nonsignificant increase in NOGD was observed after acipimox (main effect: $p=0.06$ ) (Fig. 4g). EGP in the basal state was similar on all study days, whereas acipimox induced a decrease in EGP during the HEC ( $p=0.05$ ) (Fig. 4f).

\section{Energy expenditure and protein metabolism}

Basal and insulin-stimulated energy expenditure did not change significantly in response to either $\mathrm{GH}$ or acipimox (data not shown). GH decreased protein oxidation during the HEC (main effect: $p=0.03$ ), whereas an increase was recorded after acipimox (main effect: $p=0.02$ ) (Fig. 5a). Similarly, urea turnover increased after acipimox (main effect: $p=0.01$ ) (Fig. 5b).

\section{DAG and ceramide content in skeletal muscle}

A total of 19 different species of DAGs and ceramides were identified in skeletal muscle (Table 1). Basal
DAG44:1 and ceramide CER(41:1) content decreased after GH irrespective of acipimox $(p=0.002)$. By contrast, the level of $\operatorname{CER}(42: 1)$ was unaffected by $\mathrm{GH}$ and acipimox in the basal state but increased after $\mathrm{GH}$ irrespective of acipimox during the HEC ( $p=$ 0.007). However, when adjusted for multiple testing, there was no difference between the four interventions.

\section{Insulin signalling in skeletal muscle}

Phosphorylation of Akt $\mathrm{Ser}^{473}$ was unaffected by GH and acipimox in the basal state as well as during the HEC (Fig. 6a). Basal phosphorylation of Akt substrate of $160 \mathrm{kDa}$ (AS160) $\mathrm{Thr}^{642}$ was also comparable across all study days. During the HEC, however, AS160 phosphorylation was more pronounced after $\mathrm{GH}$ alone compared with control $(p=0.02)$ and $\mathrm{GH}+$ acipimox $(p=0.03$ ) (Fig. 7b). Basal phosphorylation of glycogen synthase kinase (GSK)-3 $\alpha$ Ser $^{21}$ was similar between interventions, but during the HEC, GH increased GSK-3 $\alpha$ phosphorylation (main effect: $p=0.02$ ) (Fig. 6c). Phosphorylation of GSK-3 $\beta$ Ser $^{9}$ was similar between the interventions both in the basal period and during the HEC (Fig. 6d). Basal and insulin-stimulated phosphorylation of glycogen synthase (GS) 3a was unaffected by GH and acipimox (Fig. 6e). As expected, insulin increased the phosphorylation of Akt (main effect: $p<0.0001$ ), AS160 (main effect: $p<0.0001$ ), GSK-3 $\alpha$ (main effect: $p<0.0001$ ) and GSK-3 $\beta$ (main effect: $p<0.0001$ ) and reduced GS phosphorylation (main effect: $p<0.0001$ ).

\section{PDHa activity, PDK2 and PDK4 mRNA expression, and PDH Ser ${ }^{293}$ phosphorylation in skeletal muscle}

PDHa activity was similar between the four interventions both in the basal state and during the HEC (Fig. 7a). In response to insulin, PDHa activity increased $47 \pm 19 \%$ on the control day $(p=0.02)$ and $57 \pm 22 \%$ with acipimox alone $(p=0.02)$, but this increase was abrogated by $\mathrm{GH}(\mathrm{GH},-15 \pm 21$; $\mathrm{GH}+$ acipimox, $3 \pm 21$; GH vs control: $p=0.05$; GH vs acipimox: $p=0.03$ ) (Fig. 7b). 
Fig. 4 Glucose metabolism and insulin sensitivity. Circulating levels of glucose (a) and insulin (b) in the basal state and during the HEC presented as mean \pm SEM. GIR (c) and $M$ value (d) presented as geometric mean \pm 95\% CI. $R_{\mathrm{d}}(\mathbf{e})$, glucose oxidation (f), NOGD (g) and EGP (h) presented as mean \pm SEM. $N=7$ 9. The data were analysed by repeated measurement mixed effects model analysis. Interaction between $\mathrm{GH}$ and acipimox: $*_{p}<0.05$; main effect of $\mathrm{GH}$ : ${ }^{\dagger} p<0.05$; main effect of acipimox: ${ }^{\ddagger} p<0.05,{ }^{\star} p<0.01$, $\$ p<0.001$

Fig. 5 Protein metabolism. Protein oxidation in the basal state and during the HEC (a) and urea turnover in the basal state (b). Data are analysed by repeated measurement mixed effects model analysis and presented as mean \pm SEM, $N=7-9$. Main effect of GH: ${ }^{\dagger} p<0.05$; main effect of acipimox: ${ }^{\star} p<0.05$
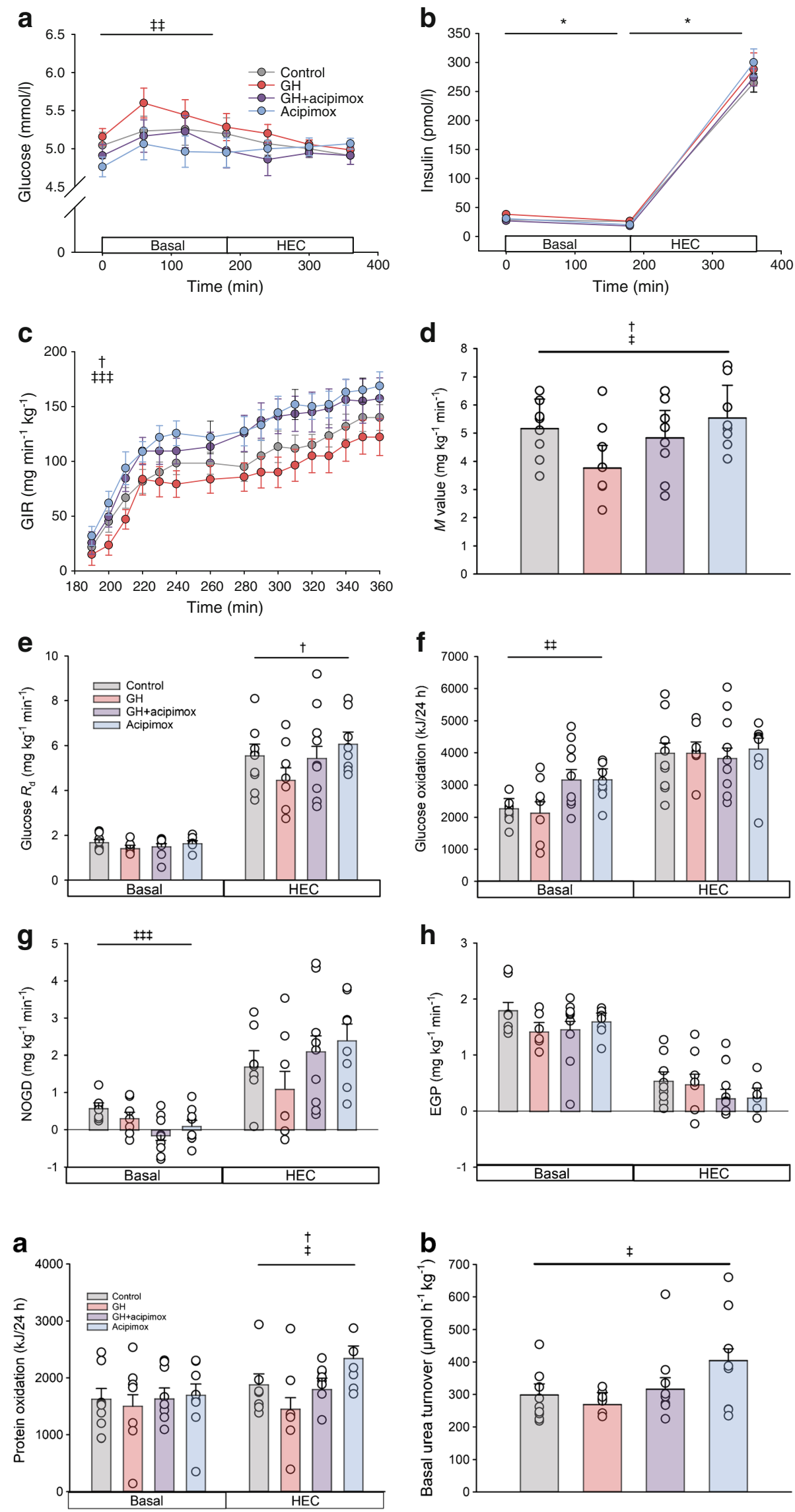
Table 1 Content of DAGs and ceramides in the skeletal muscle

\begin{tabular}{|c|c|c|c|c|c|c|c|c|}
\hline \multirow[t]{2}{*}{ Lipid } & \multicolumn{4}{|c|}{ Basal, mean $(95 \% \mathrm{CI})$} & \multicolumn{4}{|c|}{ HEC, mean $(95 \% \mathrm{CI})$} \\
\hline & Control & GH & GH+acipimox & Acipimox & Control & GH & GH+acipimox & Acipimox \\
\hline DAG32:0 & $1.0(0.6,1.5)$ & $1.5(1.0,2.2)$ & $1.9(1.3,2.8)$ & $1.4(0.9,2.1)$ & $1.0(0.7,1.5)$ & $1.3(0.8,1.9)$ & $1.2(0.8,1.7)$ & $1.5(1.0,2.3)$ \\
\hline DAG34:0 & $1.0(0.7,1.4)$ & $1.3(0.9,1.9)$ & $1.2(0.9,1.7)$ & $1.2(0.8,1.8)$ & $0.9(0.9,1.4)$ & $1.1(0.7,2.0)$ & $1.1(0.7,1.9)$ & $1.4(0.8,2.4)$ \\
\hline DAG34:1 & $1.0(0.6,1.8)$ & $1.1(0.6,2.1)$ & $1.7(1.0,3.0)$ & $1.3(0.7,2.6)$ & $0.9(0.7,1.1)$ & $0.8(0.6,1.1)$ & $0.9(0.7,1.2)$ & $1.1(0.8,1.5)$ \\
\hline DAG36:0 & $1.0(0.6,1.6)$ & $1.2(0.7,2.0)$ & $1.3(0.8,2.1)$ & $1.0(0.6,1.6)$ & $0.8(0.4,1.4)$ & $1.3(0.6,2.7)$ & $0.9(0.5,1.7)$ & $1.2(0.7,2.3)$ \\
\hline DAG36:1 & $1.0(0.7,1.4)$ & $1.1(0.8,1.5)$ & $1.3(0.9,1.8)$ & $1.4(1.0,2.0)$ & $0.9(0.7,1.3)$ & $1.0(0.7,1.3)$ & $1.1(0.8,1.5)$ & $1.1(0.8,1.5)$ \\
\hline DAG36:2 & $1.0(0.6,1.7)$ & $1.4(0.8,2.5)$ & $1.7(1.0,2.9)$ & $1.5(0.8,2.8)$ & $1.0(0.7,1.4)$ & $1.3(0.9,1.8)$ & $1.2(0.9,1.7)$ & $1.1(0.8,1.5)$ \\
\hline DAG38:0 & $1.0(0.8,1.2)$ & $1.1(0.9,1.3)$ & $1.1(0.9,1.3)$ & $1.2(1.0,1.5)$ & $1.0(0.9,1.2)$ & $0.9(0.8,1.0)$ & $1.0(0.9,1.2)$ & $1.0(0.9,1.2)$ \\
\hline DAG38:1 & $1.0(0.7,1.3)$ & $1.2(0.9,1.6)$ & $1.4(1.0,1.9)$ & $1.1(0.8,1.6)$ & $1.0(0.8,1.3)$ & $1.1(0.8,1.4)$ & $1.1(0.9,1.4)$ & $1.1(0.9,1.4)$ \\
\hline DAG42:0 & $1.0(0.7,1.5)$ & $0.7(0.5,1.1)$ & $0.7(0.5,1.1)$ & $1.3(0.8,2.0)$ & $0.8(0.6,1.1)$ & $0.7(0.5,1.1)$ & $0.9(0.6,1.3)$ & $1.0(0.7,1.4)$ \\
\hline DAG42:1 & $1.0(0.7,1.5)$ & $1.0(0.6,1.6)$ & $0.8(0.5,1.3)$ & $1.6(1.0,2.6)$ & $1.0(0.6,1.4)$ & $0.9(0.6,1.4)$ & $1.1(0.7,1.7)$ & $1.1(0.7,1.7)$ \\
\hline DAG42:2 & $1.0(0.5,2.0)$ & $0.8(0.4,1.9)$ & $0.9(0.4,1.8)$ & $1.3(0.6,2.8)$ & $0.8(0.5,1.5)$ & $0.7(0.4,1.3)$ & $1.1(0.6,1.9)$ & $0.9(0.5,1.6)$ \\
\hline DAG44:0 & $1.0(0.7,1.4)$ & $0.7(0.5,1.0)$ & $0.8(0.6,1.1)$ & $1.0(0.7,1.5)$ & $0.7(0.5,1.0)$ & $0.7(0.5,1.0)$ & $0.8(0.6,1.1)$ & $0.9(0.6,1.3)$ \\
\hline DAG44:1 & $1.0(0.7,1.4)$ & $0.7(0.5,1.1)$ & $0.7(0.5,1.0)$ & $1.3(0.8,1.9)$ & $0.8(0.5,1.1)$ & $0.7(0.5,1.1)$ & $0.9(0.6,1.3)$ & $0.9(0.6,1.3)$ \\
\hline DAG44:2 & $1.0(0.7,1.5)$ & $0.9(0.6,1.4)$ & $0.8(0.6,1.2)$ & $1.6(1.0,2.4)$ & $0.9(0.6,1.3)$ & $1.0(0.6,1.5)$ & $1.2(0.8,1.8)$ & $1.0(0.6,1.4)$ \\
\hline CER(40:1) & $1.0(0.9,1.2)$ & $1.0(0.9,1.2)$ & $0.9(0.7,1.0)$ & $1.1(0.9,1.3)$ & $0.9(0.8,1.1)$ & $1.0(0.9,1.2)$ & $1.0(0.9,1.2)$ & $1.0(0.8,1.1)$ \\
\hline CER(41:1) & $1.0(0.8,1.2)$ & $0.9(0.7,1.0)$ & $0.7(0.6,0.9)$ & $1.0(0.8,1.1)$ & $1.1(0.9,1.2)$ & $1.0(0.9,1.1)$ & $1.1(0.9,1.2)$ & $1.0(0.9,1.1)$ \\
\hline CER(41:2) & $1.0(0.8-1.2)$ & $1.0(0.8,1.3)$ & $1.1(0.9,1.3)$ & $1.0(0.8,1.3)$ & $1.0(0.8,1.3)$ & $0.8(0.6,1.1)$ & $1.0(0.8,1.3)$ & $1.0(0.8,1.3)$ \\
\hline CER(42:1) & $1.0(0.9,1.1)$ & $1.1(0.9,1.2)$ & $0.9(0.8,1.1)$ & $1.1(0.9,1.3)$ & $0.9(0.8,1.0)$ & $1.0(0.9,1.1)$ & $1.1(1.0,1.2)$ & $0.9(0.8,1.0)$ \\
\hline $\operatorname{CER}(42: 2)$ & $1.0(0.8,1.2)$ & $1.0(0.9,1.2)$ & $1.0(0.8,1.2)$ & $1.1(0.9,1.3)$ & $1.0(0.8,1.2)$ & $1.0(0.8,1.2)$ & $1.1(0.9,1.3)$ & $1.0(0.9,1.2)$ \\
\hline
\end{tabular}

Pyruvate dehydrogenase kinase (PDK) 2 and 4 phosphorylate and thereby inactivate PDH in skeletal muscle [31]. Expression of PDK2 mRNA in the basal state was decreased by GH+acipimox compared with control $(p=0.006), \mathrm{GH}(p=$ $0.01)$ and acipimox $(p=0.004)$. During the HEC, PDK2 mRNA content was similar in all four interventions with no effect of insulin (Fig. 7c). Basal PDK4 mRNA content was reduced by $\mathrm{GH}+$ acipimox as compared with control $(p=$ $0.03)$, GH $(p=0.008)$ and acipimox $(p=0.02)$ (Fig. 7d). The content of PDK4 mRNA decreased on all study days in response to insulin (main effect of time: $p<0.0001$ ). During the HEC, PDK4 mRNA expression was still decreased by $\mathrm{GH}+$ acipimox as compared with $\mathrm{GH}$ alone $(p=0.009)$ and acipimox alone $(p=0.03)$ (Fig. 7d). Phosphorylation of PDH Ser ${ }^{293}$ was comparable between all study days in the basal state and during the HEC (Fig. 7e).

\section{Discussion}

It is well documented that $\mathrm{GH}$-induced insulin resistance depends on concomitant lipolysis [15, 16, 18], and the present study was undertaken to elucidate the underlying mechanisms. Our results suggest that suppression of PDHa activity, rather than impairment of insulin signalling, promotes $\mathrm{GH}$ induced insulin resistance in skeletal muscle in humans.
The PDH complex controls the entry of carbohydratederived pyruvate into the tricarboxylic acid (TCA) cycle [32]. In line with this, we found an increase in PDHa activity in response to insulin, which is supported by most [33-36], but not all [19], previous studies. Our current observation that this increase is abrogated by $\mathrm{GH}$ suggests that $\mathrm{GH}$-induced insulin resistance involves PDH-mediated inhibition of glucose uptake. In support of this, it has previously been reported that PDHa activity is suppressed after GH exposure, fasting and high NEFA levels [19, 37, 38]. The suppressive effect of GH on PDHa activity prevailed to a minor extent during acipimox co-administration, which suggests the existence of NEFA-independent effects of GH that remain elusive.

The activity of the PDH complex is suppressed by reversible PDK-induced phosphorylation of the E1 subunits, whereas activation is mediated by $\mathrm{PDH}$ phosphatases [31]. Accordingly, the PDK4 mRNA content increases with fasting and exercise $[37,39,40]$ in a NEFA-dependent manner [40, $41]$ and the insulin-induced decrease in PDK4 mRNA expression in the present study is in line with previous reports [19, 34, 36]. The lack of $\mathrm{GH}$-associated regulation of PDK4 mRNA and PDH Ser ${ }^{293}$ phosphorylation in response to $\mathrm{GH}$ or insulin in the present study may suggest that one of the other known phosphorylation sites is involved or that other post-translational modifications such as acetylation caused the change in PDHa activity, as previously suggested [42]. 
Fig. 6 Insulin signalling in skeletal muscle. p-Akt Ser ${ }^{473} /$ total Akt (a), p-AS160 Thr ${ }^{642} /$ total AS160 (b), p-GSK3 $\alpha$ Ser $^{21} /$ total GSK $3 \alpha(\mathbf{c})$, p-GSK $3 \beta$ Ser $\% /$ total GSK $3 \beta$ (d) and p-GS $3 a$ Ser $^{641} /$ total GS 3a (e) in the basal state and during the HEC, presented as geometric mean $\pm 95 \% \mathrm{CI}$, with representative western blots (f), $N=7-9$. The data were analysed by repeated measurement mixed effects model analysis. Interaction between $\mathrm{GH}$ and acipimox: $*_{p}<0.05$; main effect of $\mathrm{GH}$ : ${ }^{\dagger} p<0.05$

\section{a}
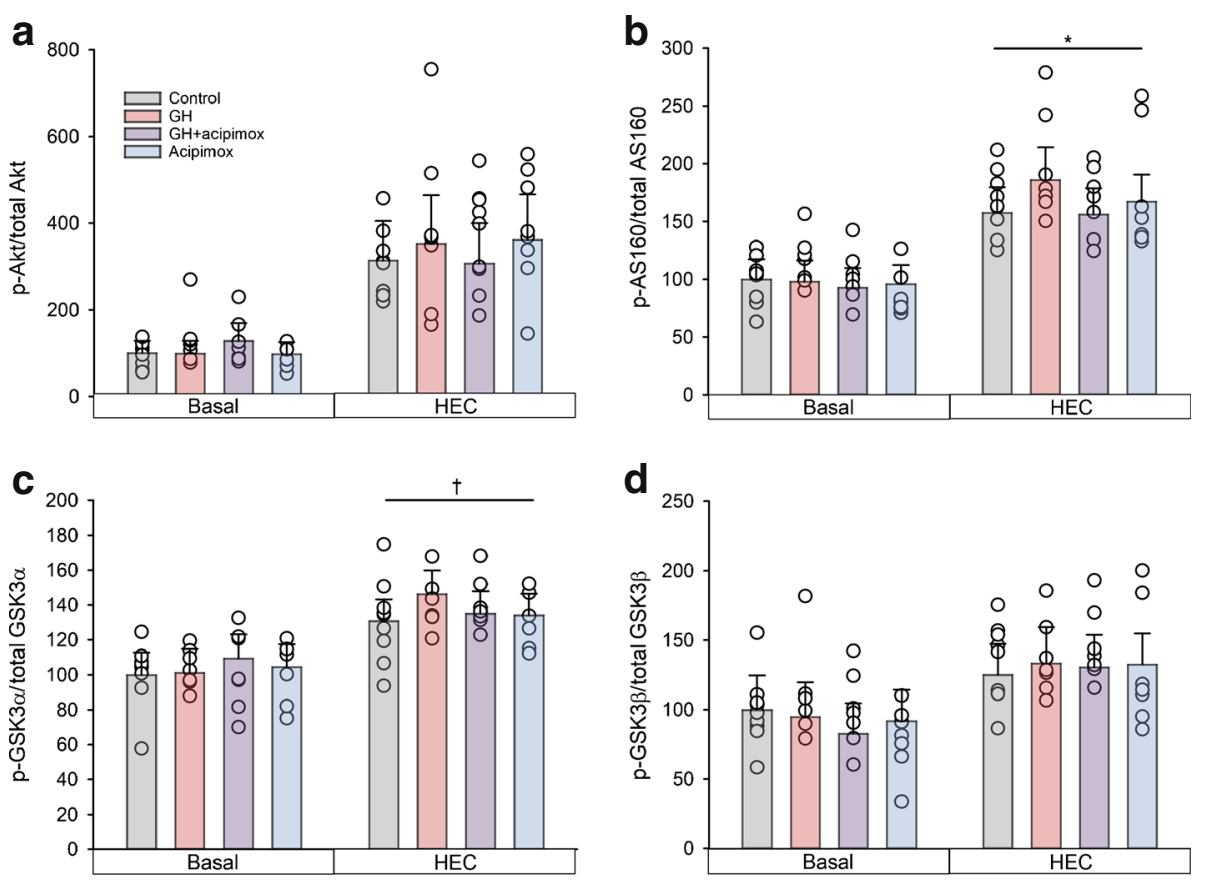

d

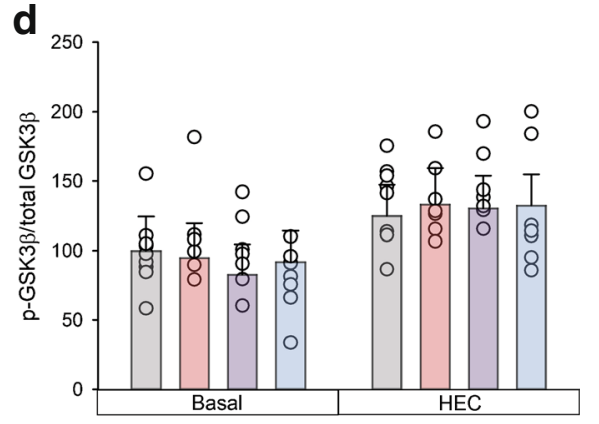

f
Intramyocellular DAGs and ceramides are suggested to be the cause of fatty acid-driven insulin resistance by the activation of protein kinase $C \varepsilon$ and $\theta[10]$ which, in turn, phosphorylate and inactivate insulin receptor substrate 1 and thereby decrease Akt activity [43]. In the present study, we therefore evaluated the content of DAGs and ceramides in human skeletal muscle during GH exposure with and without activation of lipolysis, and these results imply that GH-induced insulin resistance in skeletal muscle is unlikely to be caused by the accumulation of DAGs or ceramides. Taken together with the observation of unaltered or even, in some cases, increased phosphorylation of Akt, AS160 and GS, we conclude that GH does not suppress insulin signalling in human skeletal muscle [19, 44-46].

The observation that acipimox increases protein turnover and oxidation, which is reversed by GH, supports previous studies [47, 48]. Gluconeogenesis is decreased by nicotinic acid-induced suppression of plasma NEFA [49], and is therefore not likely to contribute to acipimox-induced ureagenesis. The protein-sparing effect of GH during fasting is partly attributed to lipolysis [47], but the present data support that GH also possesses direct protein anabolic effects.

The inclusion of GH-replaced hypopituitary patients provides a unique model for studying the interplay between $\mathrm{GH}$ and anti-lipolysis. Not only does it provide a model of fixed GH exposure, it also makes it possible to obtain sustained anti-lipolysis with acipimox, which otherwise is hampered by a rebound increase in endogenous GH secretion (triggered by low NEFA levels) that, in turn, stimulates lipolysis [50]. At the same time, we believe that our data contribute 
Fig. 7 PDH activity. Activity of PDHa in skeletal muscle in the basal state and during the HEC presented as geometric mean \pm 95\% CI (a) and the relative change in PDHa activity from the basal state to the HEC presented as mean $\pm \mathrm{SEM}(\mathbf{b})$. mRNA expression of $P D K 2$ (c) and $P D K 4$ (d) in the basal state and during the HEC presented as geometric mean $\pm 95 \%$ CI. pPDH-E $\alpha 1\left(\mathrm{Ser}^{293}\right) /$ total PDH$\mathrm{E} \alpha 1$ presented as geometric mean $\pm 95 \%$ CI (e) and representative western blot (f). The data were analysed by repeated measurement mixed effects model analysis, $N=7-9$. Interaction between $\mathrm{GH}$ and acipimox: $* p<0.05$; main effect of $\mathrm{GH}:{ }^{\dagger} p<0.05$ a

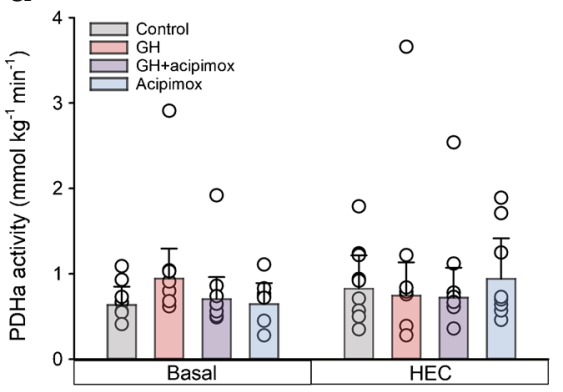

C

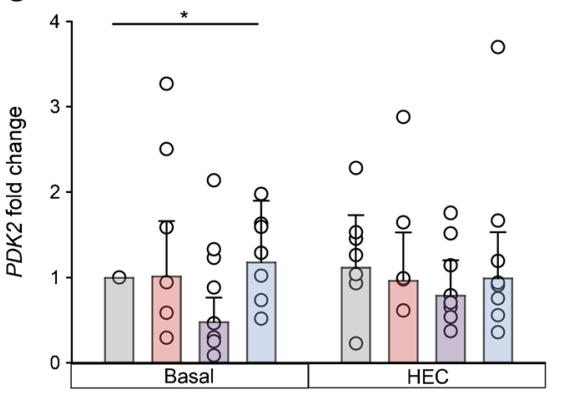

e

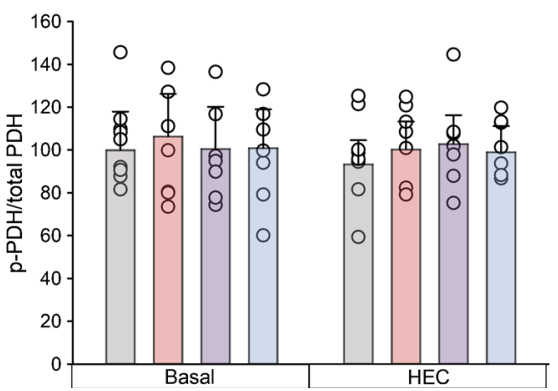

b

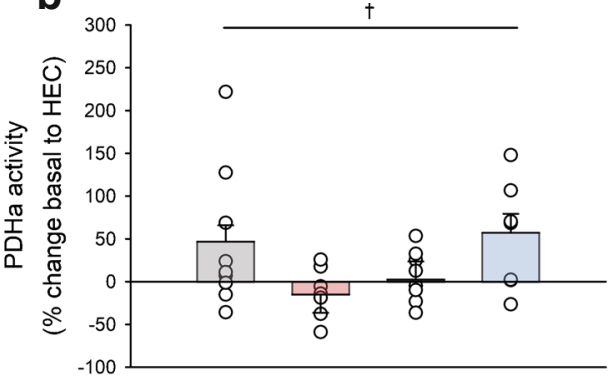

d

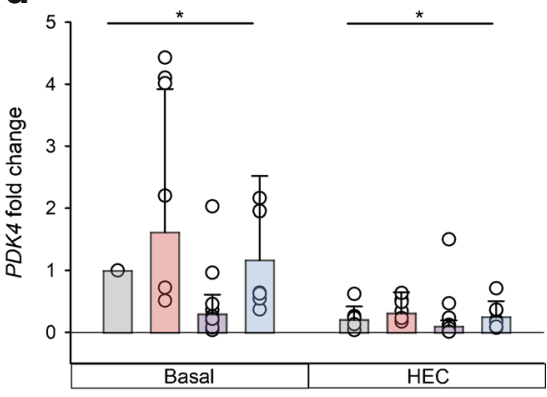

f

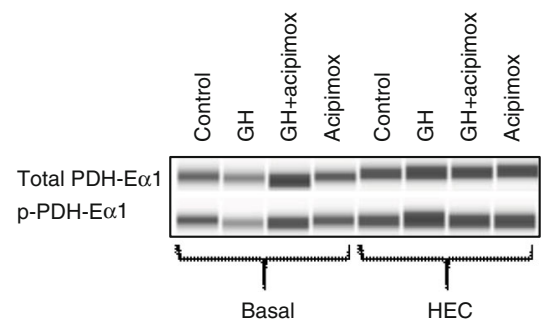

to the understanding of fatty acid-associated insulin resistance in general and we dare to challenge the hypothesis that direct impairment of insulin signalling is a crucial mechanism in human individuals in vivo.

Certain limitations of this study merit attention. First, we recorded a minor increase in serum GH levels on the acipimox day due to residual endogenous GH secretion. However, the GH levels on the acipimox day were significantly lower than on both the GH and the GH+acipimox day. Second, although mass spectrometry allowed identification of all DAGs and ceramides in the specimen, it did not discriminate between intra- and extramyocellular lipids. Finally, our sample size was relatively small, which is associated with an increased risk of a type 2 error.

In conclusion, the present study confirms that GH-induced insulin resistance is causally linked to lipolysis and provides novel evidence that this is not mediated by accumulation of DAGs and ceramides or impaired insulin signalling in skeletal muscle. Instead, the observed suppression of insulinstimulated PDHa activity suggests that substrate competition between fatty acids and glucose is involved in GH-induced insulin resistance.
Acknowledgements We are grateful for the excellent technical assistance provided by A. Mengel, H. Petersen, L. Pedersen and H. Zibrandtsen, Aarhus University Hospital. We also owe great thanks to the participants for their commitment to this study.

Data availability The datasets generated during and/or analysed during the current study are available from the corresponding author on request.

Funding The work was supported by the Grant for Growth Innovation (GGI), which was funded by Merck KGaA, Darmstadt, Germany. The study funder was not involved in the design of the study; the collection, analysis, and interpretation of data; writing the report; and did not impose any restrictions regarding the publication of the report.

Authors' relationships and activities JOLJ has received unrestricted research grants and lecture fees from Pfizer. JLG and EC were funded by the UK Medical Research Council (MC_UP_A090_1006, MC PC 13030, MR/P011705/1 and MR/P01836X/1).

Contribution statement AJH had full access to all the data in the study and takes responsibility for the integrity of the data and the accuracy of the data analysis. AJH, NJ and JOLJ designed the study. AJH, EC, SBP, $\mathrm{AG}$ and $\mathrm{HP}$ acquired the data and carried out the data analysis. AJH and JOLJ drafted the manuscript. All authors made substantial contributions to the interpretation of the results and critical revision of the manuscript. All authors approved the final version of the manuscript. 


\section{References}

1. Raben MS (1962) Growth hormone. 1. Physiologic aspects. N Engl J Med 266:31-35. https://doi.org/10.1056/ NEJM196201042660109

2. Moller N, Jorgensen JO, Schmitz O et al (1990) Effects of a growth hormone pulse on total and forearm substrate fluxes in humans. Am J Phys 258(1 Pt 1):E86-E91. https://doi.org/10.1152/ajpendo.1990. 258.1.E86

3. Hjelholt AJ, Lee KY, Arlien-Soborg MC et al (2019) Temporal patterns of lipolytic regulators in adipose tissue after acute growth hormone exposure in human subjects: a randomized controlled crossover trial. Mol Metab 29:65-75. https://doi.org/10.1016/j. molmet.2019.08.013

4. Rabinowitz D, Klassen GA, Zierler KL (1965) Effect of human growth hormone on muscle and adipose tissue metabolism in the forearm of man. J Clin Invest 44:51-61. https://doi.org/10.1172/ JCI105126

5. Gormsen LC, Jessen N, Gjedsted J et al (2007) Dose-response effects of free fatty acids on glucose and lipid metabolism during somatostatin blockade of growth hormone and insulin in humans. J Clin Endocrinol Metab 92(5):1834-1842. https://doi.org/10.1210/ jc.2006-2659

6. Yki-Jarvinen H, Puhakainen I, Koivisto VA (1991) Effect of free fatty acids on glucose uptake and nonoxidative glycolysis across human forearm tissues in the basal state and during insulin stimulation. J Clin Endocrinol Metab 72(6):1268-1277. https://doi.org/ 10.1210/jcem-72-6-1268

7. Ferrannini E, Barrett EJ, Bevilacqua S, DeFronzo RA (1983) Effect of fatty acids on glucose production and utilization in man. J Clin Invest 72(5):1737-1747. https://doi.org/10.1172/JCI111133

8. Randle PJ, Garland PB, Hales CN, Newsholme EA (1963) The glucose fatty-acid cycle. Its role in insulin sensitivity and the metabolic disturbances of diabetes mellitus. Lancet 1(7285):785-789. https://doi.org/10.1016/s0140-6736(63)91500-9

9. Boden G, Lebed B, Schatz M, Homko C, Lemieux S (2001) Effects of acute changes of plasma free fatty acids on intramyocellular fat content and insulin resistance in healthy subjects. Diabetes 50(7): 1612-1617. https://doi.org/10.2337/diabetes.50.7.1612

10. Samuel VT, Shulman GI (2012) Mechanisms for insulin resistance: common threads and missing links. Cell 148(5):852-871. https:// doi.org/10.1016/j.cell.2012.02.017

11. Dresner A, Laurent D, Marcucci M et al (1999) Effects of free fatty acids on glucose transport and IRS-1-associated phosphatidylinositol 3-kinase activity. J Clin Invest 103(2):253-259. https://doi.org/10.1172/JCI5001

12. Griffin ME, Marcucci MJ, Cline GW et al (1999) Free fatty acidinduced insulin resistance is associated with activation of protein kinase $\mathrm{C} \theta$ and alterations in the insulin signaling cascade. Diabetes 48(6):1270-1274. https://doi.org/10.2337/diabetes.48.6.1270

13. Roden M, Price TB, Perseghin G et al (1996) Mechanism of free fatty acid-induced insulin resistance in humans. J Clin Invest 97(12):2859-2865. https://doi.org/10.1172/JCI118742

14. Shulman GI (2000) Cellular mechanisms of insulin resistance. J Clin Invest 106(2):171-176. https://doi.org/10.1172/JCI10583

15. Nielsen S, Moller N, Christiansen JS, Jorgensen JO (2001) Pharmacological antilipolysis restores insulin sensitivity during growth hormone exposure. Diabetes 50(10):2301-2308. https:// doi.org/10.2337/diabetes.50.10.2301

16. Segerlantz M, Bramnert M, Manhem P, Laurila E, Groop LC (2001) Inhibition of the rise in FFA by Acipimox partially prevents $\mathrm{GH}$-induced insulin resistance in GH-deficient adults. J Clin Endocrinol Metab 86(12):5813-5818. https://doi.org/10.1210/ jcem.86.12.8096
17. Norrelund H, Nielsen S, Christiansen JS, Jorgensen JO, Moller N (2004) Modulation of basal glucose metabolism and insulin sensitivity by growth hormone and free fatty acids during short-term fasting. Eur J Endocrinol 150(6):779-787. https://doi.org/10.1530/ eje. 0.1500779

18. Salgin B, Marcovecchio ML, Williams RM et al (2009) Effects of growth hormone and free fatty acids on insulin sensitivity in patients with type 1 diabetes. J Clin Endocrinol Metab 94(9): 3297-3305. https://doi.org/10.1210/jc.2009-0378

19. Nellemann B, Vendelbo MH, Nielsen TS et al (2014) Growth hormone-induced insulin resistance in human subjects involves reduced pyruvate dehydrogenase activity. Acta Physiolog 210(2): 392-402. https://doi.org/10.1111/apha.12183

20. Tunaru S, Kero J, Schaub A et al (2003) PUMA-G and HM74 are receptors for nicotinic acid and mediate its anti-lipolytic effect. Nat Med 9(3):352-355. https://doi.org/10.1038/nm824

21. Hjelholt AJ, Sondergaard E, Pedersen SB, Moller N, Jessen N, Jorgensen JOL (2020) Growth hormone upregulates ANGPTL4 mRNA and suppresses lipoprotein lipase via fatty acids: randomized experiments in human individuals. Metabolism 105:154188. https://doi.org/10.1016/j.metabol.2020.154188

22. Steele R (1959) Influences of glucose loading and of injected insulin on hepatic glucose output. Ann N Y Acad Sci 82:420-430. https://doi.org/10.1111/j.1749-6632.1959.tb44923.x

23. Ferrannini $\mathrm{E}$ (1988) The theoretical bases of indirect calorimetry: a review. Metabolism 37(3):287-301. https://doi.org/10.1016/00260495(88)90110-2

24. Pedersen MH, Svart MV, Lebeck J et al (2017) Substrate metabolism and insulin sensitivity during fasting in obese human subjects: impact of GH blockade. J Clin Endocrinol Metab 102(4):1340 1349. https://doi.org/10.1210/jc.2016-3835

25. Harris VM (2015) Protein detection by Simple Western analysis. Methods Mol Biol 1312:465-468. https://doi.org/10.1007/978-14939-2694-7 47

26. Liu DJ, Peloso GM, Yu H et al (2017) Exome-wide association study of plasma lipids in $>300,000$ individuals. Nat Genet 49(12): 1758-1766. https://doi.org/10.1038/ng.3977

27. Cederblad G, Carlin JI, Constantin-Teodosiu D, Harper P, Hultman E (1990) Radioisotopic assays of CoASH and carnitine and their acetylated forms in human skeletal muscle. Anal Biochem 185(2): 274-278. https://doi.org/10.1016/0003-2697(90)90292-h

28. Constantin-Teodosiu D, Cederblad G, Hultman E (1991) A sensitive radioisotopic assay of pyruvate dehydrogenase complex in human muscle tissue. Anal Biochem 198(2):347-351. https://doi. org/10.1016/0003-2697(91)90437-x

29. Folch J, Lees M, Sloane Stanley GH (1957) A simple method for the isolation and purification of total lipides from animal tissues. $\mathrm{J}$ Biol Chem 226(1):497-509

30. Smith CA, Want EJ, O'Maille G, Abagyan R, Siuzdak G (2006) XCMS: processing mass spectrometry data for metabolite profiling using nonlinear peak alignment, matching, and identification. Anal Chem 78(3):779-787. https://doi.org/10.1021/ac051437y

31. Holness MJ, Sugden MC (2003) Regulation of pyruvate dehydrogenase complex activity by reversible phosphorylation. Biochem Soc Trans 31(Pt 6):1143-1151. https://doi.org/10.1042/bst0311143

32. Patel MS, Nemeria NS, Furey W, Jordan F (2014) The pyruvate dehydrogenase complexes: structure-based function and regulation. J Biol Chem 289(24):16615-16623. https://doi.org/10.1074/jbc. R114.563148

33. Mandarino LJ, Wright KS, Verity LS et al (1987) Effects of insulin infusion on human skeletal muscle pyruvate dehydrogenase, phosphofructokinase, and glycogen synthase. Evidence for their role in oxidative and nonoxidative glucose metabolism. J Clin Invest 80(3):655-663. https://doi.org/10.1172/JCI113118

34. Chokkalingam K, Jewell K, Norton L et al (2007) High-fat/lowcarbohydrate diet reduces insulin-stimulated carbohydrate 
oxidation but stimulates nonoxidative glucose disposal in humans: an important role for skeletal muscle pyruvate dehydrogenase kinase 4. J Clin Endocrinol Metab 92(1):284-292. https://doi.org/ 10.1210/jc.2006-1592

35. Pehleman TL, Peters SJ, Heigenhauser GJ, Spriet LL (2005) Enzymatic regulation of glucose disposal in human skeletal muscle after a high-fat, low-carbohydrate diet. J Appl Physiol (1985) 98(1): 100-107. https://doi.org/10.1152/japplphysiol.00686.2004

36. Tsintzas K, Chokkalingam K, Jewell K, Norton L, Macdonald IA, Constantin-Teodosiu D (2007) Elevated free fatty acids attenuate the insulin-induced suppression of PDK4 gene expression in human skeletal muscle: potential role of intramuscular long-chain acylcoenzyme A. J Clin Endocr Metab 92(10):3967-3972. https://doi. org/10.1210/jc.2007-1104

37. Spriet LL, Tunstall RJ, Watt MJ, Mehan KA, Hargreaves M, Cameron-Smith D (2004) Pyruvate dehydrogenase activation and kinase expression in human skeletal muscle during fasting. J Appl Physiol (1985) 96(6):2082-2087. https://doi.org/10.1152/ japplphysiol.01318.2003

38. Kelley DE, Mokan M, Simoneau JA, Mandarino LJ (1993) Interaction between glucose and free fatty-acid metabolism in human skeletal-muscle. J Clin Investig 92(1):91-98. https://doi. org/10.1172/Jci1 16603

39. Gudiksen A, Bertholdt L, Stankiewicz T et al (2017) Effects of training status on PDH regulation in human skeletal muscle during exercise. Pflugers Arch 469(12):1615-1630. https://doi.org/10. 1007/s00424-017-2019-6

40. Pilegaard H, Birk JB, Sacchetti M et al (2006) PDH-E1 $\alpha$ dephosphorylation and activation in human skeletal muscle during exercise: effect of intralipid infusion. Diabetes 55(11):3020-3027. https://doi.org/10.2337/db06-0152

41. Tunstall RJ, Cameron-Smith D (2005) Effect of elevated lipid concentrations on human skeletal muscle gene expression. Metabolism 54(7):952-959. https://doi.org/10.1016/j.metabol. 2005.02.012

42. Jing E, O'Neill BT, Rardin MJ et al (2013) Sirt3 regulates metabolic flexibility of skeletal muscle through reversible enzymatic deacetylation. Diabetes 62(10):3404-3417. https://doi.org/10. $2337 / \mathrm{db} 12-1650$
43. Coen PM, Goodpaster BH (2012) Role of intramyocelluar lipids in human health. Trends Endocrinol Metab 23(8):391-398. https:// doi.org/10.1016/j.tem.2012.05.009

44. Jessen N, Djurhuus CB, Jorgensen JO et al (2005) Evidence against a role for insulin-signaling proteins PI 3-kinase and Akt in insulin resistance in human skeletal muscle induced by short-term GH infusion. Am J Phys Endocrinol Metab 288(1):E194-E199. https://doi.org/10.1152/ajpendo.00149.2004

45. Nielsen C, Gormsen LC, Jessen N et al (2008) Growth hormone signaling in vivo in human muscle and adipose tissue: impact of insulin, substrate background, and growth hormone receptor blockade. J Clin Endocrinol Metab 93(7):2842-2850. https://doi.org/10. $1210 /$ jc. $2007-2414$

46. Krusenstjerna-Hafstrom T, Clasen BF, Moller N et al (2011) Growth hormone $(\mathrm{GH})$-induced insulin resistance is rapidly reversible: an experimental study in GH-deficient adults. J Clin Endocrinol Metab 96(8):2548-2557. https://doi.org/10.1210/jc. 2011-0273

47. Norrelund H, Nair KS, Nielsen S et al (2003) The decisive role of free fatty acids for protein conservation during fasting in humans with and without growth hormone. J Clin Endocrinol Metab 88(9): 4371-4378. https://doi.org/10.1210/jc.2003-030267

48. Norrelund H, Moller N, Nair KS, Christiansen JS, Jorgensen JO (2001) Continuation of growth hormone (GH) substitution during fasting in $\mathrm{GH}$-deficient patients decreases urea excretion and conserves protein synthesis. J Clin Endocrinol Metab 86(7):3120 3129. https://doi.org/10.1210/jcem.86.7.7618

49. Chen XH, Iqbal N, Boden G (1999) The effects of free fatty acids on gluconeogenesis and glycogenolysis in normal subjects. J Clin Investig 103(3):365-372. https://doi.org/10.1172/Jci5479

50. Peino R, Cordido F, Penalva A, Alvarez CV, Dieguez C, Casanueva FF (1996) Acipimox-mediated plasma free fatty acid depression per se stimulates growth hormone $(\mathrm{GH})$ secretion in normal subjects and potentiates the response to other $\mathrm{GH}$ releasing stimuli. J Clin Endocrinol Metab 81(3):909-913. https:// doi.org/10.1210/jcem.81.3.8772549

Publisher's note Springer Nature remains neutral with regard to jurisdictional claims in published maps and institutional affiliations.

\section{Affiliations}

\section{Astrid J. Hjelholt ${ }^{1,2}$ (D) Evelina Charidemou ${ }^{3}$ (D) - Julian L. Griffin ${ }^{3}$ (D) $\cdot$ Steen B. Pedersen ${ }^{1}$ (D) $\cdot$ Anders Gudiksen ${ }^{4}$ (D) Henriette Pilegaard ${ }^{4}$ (D) Niels Jessen ${ }^{2,5,6}$ (D) Niels Møller ${ }^{1}$ (D) Jens O. L. Jørgensen ${ }^{1}$ (ID}

1 Medical Research Laboratory, Department of Clinical Medicine, Endocrinology and Internal Medicine, Aarhus University Hospital, Aarhus N, Denmark

2 Department of Clinical Pharmacology, Aarhus University Hospital, Aarhus C, Denmark

3 Department of Biochemistry and Cambridge Systems Biology Centre, University of Cambridge, Cambridge, UK
4 Section for Cell Biology and Physiology, Department of Biology, University of Copenhagen, Copenhagen, Denmark

5 Steno Diabetes Centre Aarhus, Aarhus University Hospital, Aarhus N, Denmark

6 Department of Biomedicine, Aarhus University, Aarhus C, Denmark 